\title{
APOLLIŃSKOŚĆ I DIONIZYJSKOŚĆ JAKO KATEGORIE DOŚWIADCZENIA SPORTOWEGO. INTERPRETACJA PISEMNYCH RELACJI Z ULTRAMARATONÓW W ŚWIETLE TEORII RUTH BENEDICT
}

\begin{abstract}
Abstrakt. Artykuł ten poświęcony jest interpretacji tekstów z blogów o ultramaratonach, czyli biegach na dystansie dłuższym niż standardowy maraton (42,195 km). Ta subdyscyplina biegania długodystansowego obecnie prężnie się rozwija i stale przyciąga nowych uczestników, czemu towarzyszy między innymi szybko postępujący rozwój blogosfery poświęconej tej tematyce. Internetowe dzienniki biegaczy nie były jednak do tej pory analizowane zbyt obszernie przez badaczy społecznych. Dlatego w tym tekście autor podjął próbę wypełnienia tej luki empirycznej, zaś treść badanych blogów ma posłużyć do zrozumienia głębszego sensu praktyki, jaką jest uczestnictwo w ultramaratonach. Podstawą teoretyczną tej pracy są rozważania Ruth Benedict i stosowane przez nią pojęcia apollińskości oraz dionizyjskości. Pojęcia te wspomniana autorka zapożyczyła od F. Nietzschego i stosowała w opisie kultury Indian Ameryki Północnej. Głównym celem badawczym, który postawił sobie autor prezentowanego tekstu, jest próba analizy form przejawiania się apollińskości i dionizyjskości w pisemnych relacjach z ultramaratonów. Do analizy zebranych materiałów posłużyła metoda analizy dokumentów osobistych, a interpretacji poddane zostały treści tekstowe zamieszczone na blogach. W podsumowaniu znajdują się wnioski płynące z całości rozważań oraz sugestie co do dalszych badań socjologicznych.
\end{abstract}

Słowa kluczowe: apollińskość, dionizyjskość, Fryderyk Nietzsche, Ruth Benedict, ultramaratony, blogi, metoda dokumentów osobistych.

\section{Wstęp - określenie tematu i celu badawczego}

Jedną z praktyk kulturowych w ramach współczesnej przestrzeni sportu, która zdobywa obecnie coraz większą popularność, jest uczestniczenie w tak zwanych ultramaratonach, to jest biegach na dystansie dłuższym niż standardowy maraton, którego długość wynosi 42,195 km. Zawody tego typu odbywają się zazwyczaj w trudnym terenie górskim, zaś ich ukończenie zajmuje wiele godzin.

* Instytut Filozofii, Socjologii i Dziennikarstwa, Wydział Nauk Społecznych, Uniwersytet Gdański, ul. Jana Bażyńskiego 4, 80-309 Gdańsk, e-mail: adamkosznicki@gmail.com 
Ich uczestnicy po zakończonym biegu często piszą specjalne relacje poświęcone swoim wrażeniom $\mathrm{z}$ takiego wydarzenia, które zamieszczają na blogach tematycznych bądź profilach na portalach społecznościowych. I właśnie analizie tego typu treści poświęcona będzie niniejsza praca. Autor podejmie się zadania interpretacji pisemnych relacji z uczestnictwa w ultramaratonach przez pryzmat kategorii apollińskości i dionizyjskości, stosowanych w badaniach antropologicznych przez Ruth Benedict. Badaczka ta opisała za ich pomocą pewne praktyki cielesne indiańskich plemion z Ameryki Północnej. Z kolei w niniejszym opracowaniu pojęcia te będą wykorzystane do głębszego zrozumienia sensu biegania ultramaratonów, jak też pokazania, że istnieje pewna analogia między owymi indiańskimi zwyczajami a zachowaniami ludzi należących do kultury zachodniej.

Ruth Benedict nie była pierwszą, która posługiwała się pojęciami apollińskości i dionizyjskości. Przed nią w teorii literatury i teatru antycznego używał ich Fryderyk Nietzsche, on zaś oczywiście zaczerpnął je z greckiej mitologii. $\mathrm{Z}$ tego też względu porządek analizy teoretycznej w tej pracy będzie wyglądał następująco: najpierw przedstawiona zostanie charakterystyka Apolla i Dionizosa jako bogów antycznej Grecji, jako że stanowią oni model dla dalszych rozważań; następnie opisane zostanie rozumienie pojęć apollińskości i dionizyjskości przez Fryderyka Nietzschego i tego, jaką rolę pojęcia te pełniły w jego filozofii i estetyce; jako podsumowanie części teoretycznej omówione zostanie to, w jaki sposób te dwa nietzscheańskie terminy stosowała Ruth Benedict w swoich badaniach kultury Indian z amerykańskich Wielkich Równin. Część empiryczna tej pracy z kolei zawierać będzie analizę pisemnych opowieści z ultramaratonów, które zinterpretowane zostaną jako treści, w których odbywa się ukryta walka pomiędzy dwoma żywiołami - apollińskości i dionizyjskości właśnie. Poza tym podjęta będzie próba zrozumienia ogólnego sensu biegania ultramaratonów w świetle przedstawionych kategorii teoretycznych. Wyniki badań własnych zostaną też odniesione do wniosków innych badaczy eksplorujących świat biegania.

\section{Apollo i Dionizos w antycznej Grecji}

Apollo był bogiem, który symbolizował piękno, umiar, harmonię i ład we wszechświecie. Jego boskie kompetencje opisywane są następująco: „Miał on władzę nad całym życiem ludzkim. Był bogiem wiosny, bogiem podróży morskich (Delfinios), opiekował się rolnictwem i trzodami, czuwał nad zdrowiem, leczył, ale i zsyłał zarazę (Lojmios). Jako bóg wróżb i wyroczni odbierał cześć w Delfach, zwłaszcza podczas igrzysk pytyjskich (Pythios). Zsyłał natchnienie poetom, przewodził Muzom (Musagetes), był zarówno bogiem muzyki i tańca (Orchestes), jak i wszystkich sztuk. Uważany za protoplastę plemion greckich (Patroos), opiekował się miastami (Archegetes) i kierował kolonizacją grecką. Po zabiciu Pytona, będącego personifikacją ponurego świata podziemnego, zmazał winę przelewu krwi, 
dzięki czemu uchodził również za boga oczyszczenia i pokuty oraz za zbawcę (Soter)" (Piszczek 1983: 61). Fakt bycia symbolem piękna i harmonii wyrażał się również w tym, w jaki sposób Apollo był prezentowany. Przedstawiano go mianowicie jako pięknego młodzieńca o wijących się włosach, w wieńcu laurowym, z kitarą w ręku, niekiedy z wilkiem u nogi (Winniczuk 1986: 45).

Ten wieniec laurowy zdobiący głowę Apollona związany był też z jego nieszczęśliwą miłością. Zakochał się on swego czasu w muzie imieniem Dafne, jednak bez wzajemności. Ponieważ Dafne odrzucała jego zaloty, Apollo ścigał ją tak długo, aż opadła z sił. Zrozpaczona dziewczyna poprosiła swojego ojca, Penejosa, o pomoc, ten zaś zamienił ją w drzewo laurowe. Gdy Apollo ujrzał, co stało się z jego ukochaną, załamał się. Z gałęzi drzewa uplótł wieniec, który odtąd ozdabiał jego głowę ${ }^{1}$. $Z$ kolei związki Apollona ze sztuką widać najlepiej w tym, że w jego typowym wizerunku pojawia się wspomniana kitara bądź lira, które symbolizują również harmonię. Opisując tego boga greckiego, warto też wspomnieć historię o zabiciu przez niego węża zwanego Pytonem. Było to wydarzenie na tyle istotne, że dla jego upamiętnienia ustanowiono igrzyska pytyjskie. Były to igrzyska panhelleńskie, organizowane w Delfach ku czci Apollina, drugie co do ważności, po igrzyskach olimpijskich, wydarzenie o charakterze religijno-sportowym w starożytnej Grecji². Stąd kojarzy się postać Apollona również ze sportową rywalizacją i kształtującym osobowość współzawodnictwem.

Z kolei Dionizos, zwany też Bakchusem, był synem Zeusa i Semele, bogiem winnej latorośli, wina i płodnych sił przyrody (Winniczuk 1986: 117). Symbolizował przede wszystkim zabawę i brak wszelkiego umiaru, toteż stanowił radykalne zaprzeczenie Apolla. W tym aspekcie, związanym z zabawą, Dionizos najbardziej łączył się z losami ludzi: „Dionizos nauczył ludzi uprawy winnej latorośli i produkcji wina. Wędrował po wszystkich krajach na rydwanie w otoczeniu bachantek i satyrów, osłów niosących worki z winem, przy hałaśliwej muzyce aulosów i bębenków" (tamże). Na cześć Dionizosa odbywały się tak zwane Dionizje, czyli święta ku czci tego boga, obchodzone cztery razy do roku. Nazwy poszczególnych świąt przedstawiają się następująco: 1) Dionizje Małe, zwane też Wiejskimi, 2) Lenaje, 3) Antesterie, 4) Dionizje Wielkie, zwane również miejskimi (Piszczek 1983: 194). Uroczystości te wiązały się między innymi z celebrowaniem degustacji wina, jak również prezentacją sztuk teatralnych. Jednymi z najważniejszych zwycięzców tych festiwali teatralnych byli między innymi Ajschylos, Sofokles i Eurypides ${ }^{3}$. Twórczości tych autorów wiele miejsca w swoich rozważaniach poświęcił niemiecki filozof Fryderyk Nietzsche.

\footnotetext{
${ }^{1} \mathrm{https} / / /$ pl.wikipedia.org/wiki/Apollo_(mitologia) [dostęp 02.01.2018].

${ }^{2}$ https://pl.wikipedia.org/wiki/Igrzyska_pytyjskie [dostęp 02.01.2018].

${ }^{3}$ https://pl.wikipedia.org/wiki/Dionizje [dostęp 02.01.2018].
} 


\section{Apollińskość i dionizyjskość u Fryderyka Nietzschego}

Opozycja apollińskości i dionizyjskości rozważana była przez Fryderyka Nietzschego w związku z jego filozofią, estetyką oraz teorią tragedii w starożytnej Grecji. Autor ten stwierdza wprost, iż kategorie te sformułował w oparciu o mityczne postaci Apollona i Dionizosa. Pisał: „Imiona te zapożyczamy od Greków, którzy głębokie tajniki swej wizji sztuki udostępniają badaczowi nie tyle w pojęciach, ile w dogłębnie wyrazistych postaciach swego świata bogów. Do tych dwu ich bóstw, Apollina i Dionizosa, nawiązuje nasze ustalenie, że w greckim świecie istnieje zasadnicze co do źródła i celu przeciwieństwo między sztuką plastyczną, apollińską, a nieobrazową sztuką muzyki, jako sztuką Dionizosa. Te dwa tak różne popędy towarzyszą sobie, zwykle otwarcie ze sobą zwaśnione, ale obudzające się wzajem do nowych, coraz przemożniejszych porodów, aby uwiecznić w nich walkę tego przeciwieństwa tylko na pozór godzonego wspólnym słowem «sztuka»; w końcu, dzięki metafizycznemu cudownemu aktowi helleńskiej «woli», zjawiają się połączone w parę i jako taka para poczynają w końcu zarówno dionizyjskie, jak i apollińskie dzieło sztuki w postaci attyckiej tragedii" (Nietzsche 2009: 39-40).

$\mathrm{W}$ powyższej wypowiedzi, pochodzącej z początku pierwszej książki F. Nietzschego, myśliciel ten wprost powołuje się na mitologię grecką jako swoją inspirację teoretyczną. Pokazuje, że apollińskość i dionizyjskość to dwa żywioły, których relacja wygląda podobnie do ludzkich relacji między obiema płciami. Są one wobec siebie wzajemnie sprzeczne, jednak sprzeczności te dopełniają się wzajemnie, przez co rodzą się nowe jakości artystyczne. Należy zwrócić uwagę, że Apollo jest tu kojarzony ze sztuką plastyczną, która według Nietzschego ma charakter racjonalny i intelektualny. Znaczenie $\mathrm{w}$ jej przypadku jest wydobywane $\mathrm{z}$ dzieła za pomocą gruntownej interpretacji. $\mathrm{Z}$ kolei Dionizos to patron muzyki, która to jest dziedziną sztuki opartą przede wszystkim na spontaniczności i energii twórczej. W tym przypadku do znaczenia nie dochodzi się w sposób intelektualny, lecz na drodze pewnego rodzaju olśnienia, scalenia się emocjonalnego wykonawcy z odbiorcą. F. Nietzsche uważa również, że tragedia grecka przeszła ewolucję od pierwotnej dionizyjskości ku dominacji pierwiastka apollińskiego. Na ten aspekt twórczości tego myśliciela zwraca uwagę również Dennis Sweet: „Grecka tragedia wyrosła z ateńskiego święta ku czci Dionizosa - boga organicznej natury, instynktu, płodności i ekstazy. Nietzsche sugeruje, że celem ateńskich Dionizjów było doprowadzenie widza do specyficznego stanu psychicznego, w którym normalne poczucie indywidualności jest utracone, zaś doświadczenie estetyczne całościowości i jedności natury jest osiągnięte. W późniejszym rozwoju tragedii ta bezpośrednia estetyczna przyjemność (aesthetischen Genuss) znika poprzez dialogi aktorów, wątki, scenografię oraz inne teatralne pułapki. Jednak we wczesnych sztukach Ajschylosa można dostrzec próbę ponownego osiągnięcia pierwotnej estetycznej przyjemności Dionizjów nie przez uniknięcie tych dialogowych pułapek, lecz przez połączenie je w specyficzny sposób" (Sw eet 1999: 354). 
Nietzsche porównuje też relację między apollińskością a dionizyjskością do relacji snu oraz zmysłowego upojenia. Ten pierwszy stan kojarzony jest z postacią Apolla: „To radosne poczucie konieczności doświadczenia snu wyrazili również Grecy w osobie swego Apollina. Jako bóg wszelkich sił plastycznych, Apollo jest również bogiem prawdomównym. Z natury będąc «świetlistym», bóstwem światła, włada też pięknym pozorem wewnętrznego świata fantazji. Wyższa prawda, doskonałość tych stanów w przeciwieństwie do fragmentarycznie rozumianej dziennej rzeczywistości, a następnie głębokie poczucie uzdrawiającej i pomocnej we śnie i w sennym marzeniu natury stanowią zarazem symboliczną analogię do uzdolnień wróżbiarskich i w ogóle do sztuk, które czynią życie możliwym i wartym życia" (Nietzsche 2009: 42). Z kolei domeną Dionizosa jest stan upojenia: „Pod wpływem narkotycznego napoju, o którym mówią w hymnach wszystkie pierwotne ludy i narody, lub wskutek gwałtownego, całą naturę namiętnie przenikającego nadejścia wiosny budzą się owe dionizyjskie podniety, a wobec ich przyboru subiektywność znika w zupełnym samozapomnieniu. Także w niemieckim średniowieczu pod wpływem tej samej dionizyjskiej siły rosły gromady, wędrując z miejsca na miejsce wśród śpiewu i tańca" (ta mże: 44). Warto też zaznaczyć, że apollińskość i dionizyjskość nie były dla Nietzschego równoważne, opowiadał się on zdecydowanie za tym drugim elementem. Jak podaje W. Tatarkiewicz: „Wywodził, że w niej miało źródło wszystko, co w dziejach było wielkie, potężne i twórcze. Nawet grecka kultura, wydająca się tak bardzo apollińską, była wedle Nietzschego w osnowie swej dionizyjska" (1988: 168). Tego typu rozważania niemieckiego filozofa stały się z kolei teoretycznym punktem odniesienia dla amerykańskiej antropolog Ruth Benedict.

\section{Apollińskość i dionizyjskość u Ruth Benedict}

Ruth Benedict stosowała pojęcia apollińskości i dionizyjskości w swoich badaniach nad pierwotnymi ludami zamieszkującymi terytoria Ameryki Północnej. Według niej terminy te najlepiej oddają różnicę między plemieniem Indian Pueblo a innymi plemionami przez nią badanymi. Badaczka ta powołuje się wprost na myśl F. Nietzschego i w nawiązaniu do niego podaje dwie metody dochodzenia do pojęcia istnienia: „Dionizyjczyk dąży do «zniweczenia powinności i wynikających z nich ograniczeń egzystencji», w najbardziej istotnych dla siebie momentach stara się uciec przed ograniczeniami, które nakłada na niego własne pięć zmysłów, uzyskać doświadczenie innego rzędu. Pragnieniem dionizyjczyka w przeżyciu osobistym czy w rytuale jest osiągnięcie z jego pomocą pewnego stanu psychicznego, którego istotą jest brak umiaru. Najbliższą analogię do emocji, których szuka, stanowi stan upojenia alkoholowego, najwyżej ocenia oświecenie zdobyte w przystępie szału. [...] Apollińczyk potępia taką postawę i często ma tylko słabe pojęcie o naturze tego rodzaju przeżyć. Znajduje on sposoby usunięcia 
ich poza swoje życie świadome. «Zna tylko jedną zasadę: umiar w rozumieniu helleńskim». Trzyma się złotego środka, nie wychodzi poza utarte szlaki, nie ulega rozprzężeniu psychicznemu. Nawet $\mathrm{w}$ uniesieniu tańca «pozostaje sobą, zachowuje - według pięknych słów Nietzschego - swą obywatelską godność»" (Benedict 2011: 163).

Przykładem plemienia apollińskiego byli według Ruth Benedict Indianie Pueblo. Należy jednak zauważyć, że samo znaczenie terminów apollińskości i dionizyjskości w kontekście kultury indiańskiej nie jest tożsame ze znaczeniem tych terminów w starożytnej Grecji. Jak podaje R. Benedict: „Nie wszystkie z twierdzeń Nietzschego dotyczących kontrastu między apollińczykami a dionizyjczykami da się zastosować, mówiąc o kontraście, jaki istnieje między Indianami Pueblo a otaczającymi ich ludami. [...] Opisując układy kulturowe krajowców Ameryki, nie posługuję się terminami zapożyczonymi z kultury greckiej, aby stawiać znak równości między cywilizacją Grecji a cywilizacją tubylców amerykańskich. Używam ich, ponieważ są to kategorie, które wyraźnie wysuwają na czoło główne cechy odróżniające kulturę Indian Pueblo od kultur innych Indian amerykańskich, nie zaś dlatego, że wszystkie postawy, które spotykamy w dawnej Grecji, spotykamy również u tubylców Ameryki" (Benedict 2011: 164). Zasadniczą różnicą w apollińskości kultury Indian Pueblo i Greków było to, że ci pierwsi byli znacznie bardziej apollińscy niż ci drudzy. Istotna była tutaj jedna z fundamentalnych cech apollińskości, jaką jest indywidualizm. Dla Greków był on ważną cechą człowieka, ale jego wpływy były łagodzone przez inne czynniki społeczne, natomiast dla Indian Pueblo skupienie się na sobie i niechęć do zmiany stanowiły fundament ich kultury. Jak podaje R. Benedict: „Pozostać zawsze w pewnych granicach to tyle, co zaufać precedensowi, tradycji. Dlatego wpływy, które silnie się jej przeciwstawiają, nie znajdują w ich zwyczajach sympatii i są pomniejszane, a już najbardziej indywidualizm. Zgodnie z apollińską filozofią południowego zachodu jest on zgubny nawet wtedy, kiedy udoskonala i rozszerza tradycję" (Benedict 2011: 164).

Indianie Pueblo ze swoją kulturą radykalnie różnili się od otaczających ich plemion krajowców amerykańskich, które były zdecydowanie dionizyjskie w swoich praktykach. Według R. Benedict: „Indianie amerykańscy w ogóle, w tym także Indianie meksykańscy, byli gorliwymi dionizyjczykami. Cenili wszelkie gwałtowne przeżycia, wszelkie środki pozwalające ludziom na wyłamanie się z normalnej rutyny zmysłowych odczuć i wszelkim tego rodzaju przeżyciom przypisywali największą wartość" (Benedict 2011: 165). Ten kult dionizyjskości był swego rodzaju najniższym wspólnym mianownikiem kultur wszystkich Indian otaczających terytoria należące do Pueblo. Podstawowe praktyki dionizyjskie miały prowadzić do osiągania wizji, zaś drogą do ich uzyskania było stosowanie wobec siebie samego tortur: „Na równinach zachodnich ludzie starali się o osiągnięcie stanu wizji z pomocą przerażających tortur. Zdzierali paski skóry z ramion, odcinali sobie palce, zwieszali się z wysokich słupów na pasach zakładanych pod pachy. 
Niezwykle długi czas wytrzymywali bez pokarmu i wody. Na wszelkie sposoby starali się osiągnąć przeżycie wykraczające poza życie codzienne. Na równinach do uzyskania wizji dążyli ludzie dorośli. Niekiedy stali bez ruchu, z rękami związanymi z tyłu, albo też wytyczali mały kawałek ziemi, z którego nie mogli się ruszyć, dopóki nie uzyskali błogosławieństwa w postaci wizji. Czasem wędrowali w dalekie, niebezpieczne strony. Niektóre plemiona wybierały przepaści i miejsca szczególnie zagrożone. W każdym przypadku człowiek udawał się tam sam lub jeśli szukał wizji z pomocą tortur i ktoś musiał pójść z nim, aby przywiązać go do słupa, z którego miał zwisać, dopóki nie osiągnie nadprzyrodzonego przeżycia, pomocnik wykonywał, co do niego należało i zostawiał go samego na czas tej ciężkiej próby" (tamże: 165-166).

Wizjom osiąganym przez Indian przypisywało się pewne określone cechy. Do najważniejszych z nich należały: 1) stosowanie tortur wobec siebie, 2) brak rozróżnienia na laickość i szamanizm, 3) osiąganie ducha strażniczego (Bene dict 1922: 3). Poza tym R. Benedict wskazywała na takie cechy, jak skoncentrowanie się na aktualnym doświadczeniu, uzyskiwanie przez wizje powodzenia w życiu i rozmaitych szczególnych cech (siły przy okazji działań wojennych, daru leczenia itp.) czy też doznawanie zaburzeń zmysłowych w postaci halucynacji (Benedict 2011: 166-167). Wizje łączyły się też z kontaktem z przyrodą, gdyż istniały plemiona, które szczególnie ceniły chwile zbliżenia z naturą, kiedy to człowiek siedząc sam nad brzegiem rzeki lub tropiąc zwierza, wyczuwał w zwykłym zjawisku jakieś niezwykłe znaczenie (tamże: 167). Z kolei z tym „wyczuwaniem «niezwykłego zdarzenia»” łączy się jeszcze jedna cecha wizji, jaką jest ich subiektywność. O tym, czy dane doświadczenie będzie uznane za ponadnaturalne poznanie zmysłowe, decydował ten, kto go sam doświadczył. Wizje, które nie miały cechy wyjątkowości w mniemaniu osoby ich doznającej, były lekceważone.

\section{Metodologia badania - blogi jako przedmiot eksploracji socjologicznej}

Po przedstawieniu teoretycznych założeń tej pracy przyszła pora na omówienie metodologicznej charakterystyki przeprowadzonego badania, a wiąże się to głównie z potraktowaniem bloga jako obiektu badawczego dla socjologa. Po pierwsze, należy sobie zadać pytanie, czy taki dokument, jakim jest dziennik internetowy prowadzony przez biegacza, jest bardziej narzędziem czy raczej przedmiotem analizy? Jeśli patrzeć na niego jako na narzędzie badawcze, to może on posłużyć do prowadzenia eksperymentów oraz obserwacji (Jeran 2004: 181). W takim ujęciu istotna stanie się ta część bloga, która pozwala na rejestrowanie zachowań autora bloga oraz czytelników. Dotyczy to przede wszystkim 
komentarzy pod poszczególnymi postami, dzięki którym czytelnicy mogą wejść w relację z autorem i udzielić mu informacji zwrotnej, dotyczącej tego, co myślą o jego tekstach.

Z kolei w traktowaniu internetu jako przedmiotu badań kluczowe będzie badanie treści tekstów (Jeran 2004: 181). W takim ujęciu istotne staną się posty tworzone przez samego autora danego bloga oraz ich interpretacja dokonana przez badacza. W niniejszym badaniu przyjęto drugą $\mathrm{z}$ wymienionych perspektyw ujmowania badań prowadzonych $w$ internecie. Pominięte zostało pierwsze z wymienionych podejść, jako że łączy się głównie z pozytywistycznym ujmowaniem zjawisk społecznych. Skupia się ono na obserwowalnych zachowaniach i ich obiektywnych cechach. Z kolei w badaniu, którego wyniki przedstawione są poniżej, autor przyjął podejście bardziej humanistyczne i interpretatywne. Kluczowe stało się poznanie subiektywnych znaczeń zawartych w treści poszczególnych blogów odnoszących się do biegania ultramaratonów.

Skoro przyjęto założenie, że blog będzie traktowany jako przedmiot badania, pojawia się kolejne pytanie. Dotyczy ono tego, jakie funkcje, istotne z punktu widzenia badania socjologicznego, może on w takim ujęciu pełnić. Najważniejsza funkcja dla dalszych rozważań polega na tym, że blogi są formą autoprezentacji i kreowania siebie w sieci (Szpunar 2005: 399). Ich prowadzenie pozwala autorowi z jednej strony oderwać się od codzienności, z drugiej natomiast dowolnie kreować swój wizerunek wobec odbiorców. Aspekt oderwania się autorów blogów od codzienności opisuje M. Olcoń-Kubicka: „W życiu codziennym są członkami społeczeństwa, są konkretnymi jednostkami w strukturze społecznej i pełnią w niej określone role. Są dziećmi, rodzicami, studentami, artystami, urzędnikami. Ich status jest wyznaczany przez to, co społeczeństwo ceni najbardziej i czemu przypisuje określony prestiż. Decydując się na wejście do wirtualnej wspólnoty, rezygnują z dotychczas przypisywanych im statusów i przybierając sobie nowe imię, wkraczają w strefę gry, gdzie struktura społeczna i odpowiadająca jej hierarchia zostaje zawieszona. W ramach blogowej rzeczywistości kreują sobie postać, jaką chcą odgrywać i postępują zgodnie z jej charakterem" (Olcoń-Kubicka 2006: 154). Z kolei odnosząc się do kwestii tworzenia nowej tożsamości przez prowadzenie bloga, ta sama autorka podaje: „Prowadzenie publicznych zapisków stwarza autorowi szansę stworzenia pewnej tożsamości zbudowanej na podstawie własnych przeżyć i ukształtowanej w oparciu o prywatne upodobania i gusta. Taka tożsamość, czyli specyficznie wypracowana wizja mojego «ja» prezentowana jest szerszej publiczności do oceny. Możliwość ekspresji oraz «testowania» starannie wypracowanej kreacji własnej osobowości jest z pewnością czynnikiem przyciągającym ludzi do blogowania. Kreacja taka wymaga odpowiedniej oprawy, czyli starannie wypracowanego wizerunku, ponieważ umieszczenie swojego dziennika w przestrzeni wirtualnej zakłada obecność innych i ich oceniające spojrzenie, dlatego też autor musi wykonać pewien wysiłek, aby jego wizerunek przypadł do gustu innym" (tamże: 155). 
W kontekście blogów poświęconych bieganiu, w tym również ultramaratonom, w kreowaniu siebie ważne stają się w szczególności opisy dotyczące tej właśnie aktywności sportowej - procesu prowadzonego treningu, startów w zawodach, relacji z innymi biegaczami, całej sfery psychicznej, mentalnej i emocjonalnej związanej z bieganiem itp. Poza tym poszczególne posty temu poświęcone obserwowane razem tworzą jedną wspólną całość, która przez odwołanie do literatury określana jest jako „powieść odcinkowa”. Jak podaje Olcoń-Kubicka: „Blog jest nieustającym dialogiem - przypomina bardziej pisanie powieści odcinkowej, gdzie autor rozwija kolejne wątki na życzenie czytelników. Podobnie autor dziennika na prośby komentatorów może zdawać kolejne relacje ze swojego życia uczuciowego, zmagań z szefem w pracy czy podróży do innego miasta. Mimo że istnieją teksty podobne $\mathrm{w}$ formie do tradycyjnych dzienników, nastawione przede wszystkim na relację o przeżyciach autora, a także zdające się iść własnym nurtem i nie reagujące na specyfikę blogowego otoczenia, to o ile autor nie wyłączy opcji komentarzy, w pewnym momencie ujawnia się oddziaływanie komentatorów" (2006: 155).

Podstawą empiryczną dla rozważenia relacji między żywiołem apollińskości i dionizyjskości w opisach uczestnictwa w biegach ultramaratońskich będą dwa blogi internetowe: „Być jak Filipides” oraz „Lepiej Biegać”. Pierwszy z nich zawiera dwuczęściową relację z Biegu Rzeźnika w 2015 r. ${ }^{4}$, natomiast drugi opis rywalizacji z tej samej imprezy w edycji z 2017 r. ${ }^{5}$ Wybór akurat tych dwóch dzienników internetowych podyktowany był kilkoma względami. Po pierwsze, obydwa zawierają wyczerpujące relacje $\mathrm{z}$ uczestnictwa w ultramaratonach górskich. Przez swoją głębię teksty te pozwalają na przeanalizowanie sposobów przejawiania się apollińskości i dionizyjskości w uprawianiu biegania na najdłuższych dystansach. Po drugie, oba przedstawione blogi i zawarte na nich wpisy dotyczą tej samej imprezy sportowej. Choć nie jest to edycja z tego samego roku, to jednak za każdym razem odbywa się ona w podobnej formie, więc obie relacje powinny zawierać treści pozwalające na dokonywanie porównań. Po trzecie, autorzy tych blogów są już doświadczonymi ultramaratończykami, co można stwierdzić na podstawie liczby wpisów poświęconych udziałowi w biegach górskich na dystansach ultra. $\mathrm{Z}$ tego względu ich relacje można uznać za w dużym stopniu merytoryczne i oparte na doświadczeniu. Poza tym dowodzi to też obycia z tego typu wydarzeniami, przez co można przyjąć, że treści poszczególnych wpisów będą skupiać się na sprawach istotnych w danych zawodach, nie zaś na rzeczach pobocznych.

Ale zanim przedstawiona zostanie analiza zebranego materiału empirycznego, należy jeszcze wspomnieć o metodologicznych aspektach stosowania pojęć apollińskości i dionizyjskości w badaniach. Dotyczy to problemu konkretności

${ }^{4}$ http://bycjakfilipides.pl/najdluzszy-dzien-czyli-xii-bieg-rzeznika-cz-1/ oraz http://bycjakfilipides.pl/najdluzszy-dzien-czyli-12-bieg-rzeznika-cz-2/ [dostęp 02.01.2018].

${ }^{5} \mathrm{https} / / /$ lepiejbiegac.pl/2017/06/bieg-rzeznika-ultra-140/ [dostęp 02.01.2018]. 
i realności tych kategorii w obserwowalnych empirycznie zjawiskach społecznych, na który zwraca uwagę A. Kłoskowska we wstępie do książki R. Benedict. A. Kłoskowska sugeruje, że te pojęcia należy ujmować raczej jako typy idealne w Weberowskim sensie, to jest jako teoretyczne konstrukcje nieznajdujące ścisłego odpowiednika w rzeczywistości empirycznej, ale zdolne służyć do rozumienia i porządkowania empirycznych zjawisk (Kłoskowska 2011: 49). Tak też uczyniono w niniejszym badaniu. Wybrano dwa blogi, aby można było dokonywać między nimi porównań, podobnie jak porównań dokonywała R. Benedict w swojej analizie kultur indiańskich. Nie przyjęto jednak założenia, że jeden z blogów jest przykładem czystej apollińskości, drugi zaś czystej dionizyjskości. Zamiast tego wybrano różne fragmenty $\mathrm{z}$ analizowanych wypowiedzi, aby zaprezentować pewnego rodzaju ukryty dialog między tymi dwoma żywiołami, który odbywał się w umysłach autorów poszczególnych wpisów. Zatem celem badawczym było zaprezentowanie, jak apollińskość i dionizyjskość toczą ukrytą walkę w duszy ultramaratończyka, a tym samym stanowią o pewnej ogólnej charakterystyce kultury uczestników tego typu zawodów. Co więcej, w artykule tym nie było miejsca na całościową interpretację badanych tekstów. $Z$ tego też względu posłużono się w pewnym sensie reprezentatywnymi wyimkami z analizowanych wpisów, które jednak były wystarczającym materiałem do wyciągnięcia ogólnych wniosków, jak również zaprezentowania czytelnikowi toku rozumowania badacza.

\section{Apollińskość i dionizyjskość w relacjach pisemnych $\mathrm{z}$ ultramaratonów}

Apollińskość w bieganiu ultramaratonów w ogólności, jak również w treści każdej z analizowanych relacji, przejawia się głównie w aspekcie sportowym tej formy aktywności. Jak wspomniano w opisie postaci Apollona w mitologii starożytnych Greków, był to patron piękna, dążenia do doskonałości, wewnętrznej równowagi oraz harmonii, a są to cechy powszechnie kojarzone z rozwojem sportowym oraz rywalizacją, tak z samym sobą, jak też z innymi ludźmi. Dodajmy, że bóg ten był opiekunem igrzysk pytyjskich, co jeszcze mocniej utwierdza jego wizję jako opiekuna sportu. Na blogu „Być jak Filipides” apollińskość w takim rozumieniu przejawia się przede wszystkim w porównaniu przygody sportowej do historycznego wydarzenia, jakim było lądowanie aliantów w Normandii 6 czerwca 1944 r. Autor zatytułował swój wpis dotyczący startu w Biegu Rzeźnika z 2015 r. „Najdłuższy dzień, czyli XII Bieg Rzeźnika”, przez co odwołał się do znanej książki historycznej o II wojnie światowej: „Jest taka książka «Najdłuższy dzień», napisał ją Cornelius Ryan, opowiadała o 6 czerwca 1944 roku, czyli o D-Day, jednym z najważniejszych wydarzeń w historii II wojny światowej. Mój najdłuższy dzień miał miejsce dokładnie 70 lat i 354 dni później, 5 czerwca podczas XII Biegu Rzeźnika i także było to jedno z najważniejszych wydarzeń, 


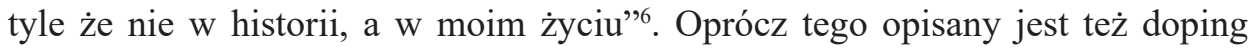
kibiców i satysfakcja z ukończonego biegu: „Doping ze wszystkich stron, słyszę - Dawaj Bartek!!! - Patrzę w bok i widzę mojego znajomego, Bartka, z którym kończyliśmy maraton w zimie, a który dziś też biegł. Niesie mnie ten doping, już ją widać!!! Zaczynam sadzić ogromne susy, nic się nie liczy, mijamy metę Biegu Rzeźnika po 15 godzinach 37 minutach i 18 sekundach. Na mecie walimy się na kolana, mnie z kącików oczu płyną łzy, wolontariuszka uśmiechnięta cicho mówi - gratuluję - zawieszając mi na szyi ręcznie robiony medal. Przybijamy z Wojtkiem piątkę, dziękując sobie wzrokiem za ten wspólny wysiłek, a chwilę później zanurzamy usta w zimnym browarze"

Z kolei w przypadku drugiego z blogów element apollińskości, która łączy się $\mathrm{z}$ aspektem sportowym biegania ultramaratonów, dotyczył głównie planowania całego startu oraz wyciągania zeń wniosków. Autor pierwszego z omawianych blogów był raczej amatorem, dla którego tego typu wydarzenie to w znacznej mierze przygoda w czasie wolnym, natomiast autor drugiego jest bardziej doświadczony, o czym najlepiej świadczy choćby to, że w swoim biegu zajął czwarte miejsce w klasyfikacji ogólnej, a drugie w swojej kategorii wiekowej. Dokładnie też zaplanował sobie start w zawodach: „Strategia: Tempo - zacząć bardzo spokojnie i oszczędzać siły na później. Bieg według ustalonej czasówki i nie gonić; podejścia i zbiegi - Podejścia pokonywać mocnym marszem, z użyciem kijów. Zbiegi niezbyt szybko, żeby nie «zaklepać» nóg zbyt wcześnie; odżywianie - posiłek i kawa przed biegiem, regularne jedzenie - pierwszy posiłek po godzinie biegu, kolejno małymi kęsami, ale często, przynajmniej co 40 minut. Jedzenie na punktach - byle nie zbyt dużo, żeby nie obciążyć zbyt mocno żołądka; nawadnianie - minimum 0,5 1 płynów na każdą godzinę biegu. Woda do popijania batonów, izotonik pomiędzy (to dodatkowe, łatwo przyswajalne węglowodany). Mniej więcej do każdego punktu żywieniowego powinienem dobiegać z pustymi butelkami - jeśli coś zostało, to znaczy, że za słabo się nawadniam"».

Jeśli zaś chodzi o dionizyjskość, to przejawia się ona przede wszystkim w potrzebie doznawania skrajnych doświadczeń cielesnych i wysiłku. Teza ta jest poniekąd odpowiedzią na pytanie o cel uczestnictwa w ultramaratonach. Jeśli przyjąć założenie, że człowiek jako stworzenie biologiczne dąży do unikania cierpień i maksymalizowania przyjemności, to co takiego pcha niektórych do zadawania sobie skrajnie wysokiego cierpienia związanego z wysiłkiem? Odpowiedzią może być tylko stwierdzenie, że w mentalności ultramaratończyków pojawiają się elementy kultury dionizyjskiej. Te same czynniki, które motywowały Indian z Ameryki Północnej do zadawania sobie tortur i chęci osiągania wizji, pchają wielu ludzi do uczestnictwa w wielogodzinnych biegach. Oto jak wygląda przykładowy

\footnotetext{
${ }^{6} \mathrm{http} / /$ /bycjakfilipides.pl/najdluzszy-dzien-czyli-xii-bieg-rzeznika-cz-1/ [dostęp 02.01.2018].

${ }^{7} \mathrm{http}: / /$ bycjakfilipides.pl/najdluzszy-dzien-czyli-12-bieg-rzeznika-cz-2/ [dostęp 02.01.2018].

${ }^{8}$ https://lepiejbiegac.pl/2017/06/bieg-rzeznika-ultra-140/ [dostęp 02.01.2018].
} 
opis tego typu doświadczeń: „Trochę bólu, sporo stęknięć i niewybrednych przekleństw, później pojawia się szczyt. Wyłażę z lasu wprost na opalających się na ławce turystów, którzy przestają coś przeżuwać i patrzą się na mnie z otwartymi paszczami, niczym na jakiegoś dzikusa, który dotarł na skraj cywilizacji. Minąłem ich i poczłapałem wytartym szlakiem wzdłuż pasma Otrytu. Czuć w powietrzu żar południa, ale na szczęście gęsty las rozwija baldachim chroniący przed palącymi promieniami słońca. W pewnej chwili uświadamiam sobie, że oddycham bardzo płytko. Zaciągnąłem mocno powietrze $\mathrm{w}$ płuca... i aż się zgiąłem z bólu... kilkanaście godzin ciągłej pracy zgasiło moje miechy i dopiero po kilku głębokich wdechach i wydechach zaczęły z powrotem tłoczyć powietrze jak trzeba. Żołądek też już wywiesza sztandary protestu przeciw cukrowi. Kompromis znajdujemy w bakaliach".

$\mathrm{Z}$ treści zaprezentowanych fragmentów wpisów widać zatem, że w umyśle biegaczy uprawiających ultramaratony współistnieją dwa żywioły - apolliński i dionizyjski. Ludzie ci łączą w sobie cechy tych dwóch postaw, które odróżniały Indian Pueblo od innych plemion z Wielkich Równin. Z jednej strony można zaobserwować, że ultramaratończycy szukają harmonii i spokoju ducha, z drugiej natomiast pragną, świadomie bądź nieświadomie, skrajnego doświadczenia cielesnego, czegoś na kształt szału czy manii. Pojawia się zatem kolejne pytanie, które dotyczy tego, jak wyglądają wzajemne relacje między apollińskością i dionizyjskością u ultramaratończyków? Czy oba te żywioły są równie silne, czy może jeden z nich jest przeważający? Czy oba pojawiają się w tym samym czasie, czy może raczej zachodzi tu proces zastępowania jednego przez drugi? Warto się w tym przypadku odwołać do J. R. Stempnia, który prowadził badania wśród uczestników maratonów ulicznych i przyjmował nietzscheańską perspektywę teoretyczną, podobnie jak autor w niniejszej pracy. Stempień powoływał się na pojęcie woli mocy, jako centralne dla filozofii F. Nietzschego. Z jego badań wynika ogólny wniosek, że u maratończyków dochodzi do transformacji - od pierwotnej motywacji prozdrowotnej przechodzi się do fazy naginania możliwości własnego organizmu, nawet kosztem zdrowia. Badacz ten opisuje to następująco: „Bieganie - początkowo swoiste instrumentum, będące środkiem do zadbania o własne zdrowie i ciało - nabiera dodatkowych walorów, dostarczając (nieoczekiwanych, jak się zdaje) satysfakcji, związanych z doświadczaniem możliwości własnego ciała. Satysfakcje te wymagają dalszych inwestycji czasu i energii, aby utrzymać i rozwijać raz zbudowaną kondycję fizyczną" (Stempień 2016: 54). J. R. Stempień nie wspomina tu o pewnej rzeczy, a mianowicie o konieczności doświadczania fizycznego dyskomfortu związanego z treningiem i startami w zawodach, którego trzeba doświadczyć, aby następnie doznać wspomnianej satysfakcji. Można by zatem powiedzieć, że przemawia to za dominacją pierwiastka dionizyjskiego u biegaczy na najdłuższych dystansach, bo liczy się dla nich skrajne fizyczne

\footnotetext{
${ }^{9}$ https://lepiejbiegac.pl/2017/06/bieg-rzeznika-ultra-140/ [dostęp 02.01.2018].
} 
doświadczenie. Istnieją też inne badania biegaczy długodystansowych, które pozwalają uznać, że to jednak pierwiastek apolliński jest dominujący. Wniosek taki sugeruje A. Czerner, która podkreśla autoteliczność wysiłku u biegaczy. Według niej: „Autoteliczność rozumiana jest tu w tym sensie, że cielesność odrywa się od wymiaru ściśle funkcjonalnego, stając się ważnym, widocznym dla otoczenia, markerem tożsamości - oto widzimy nie zwykłe ciało, lecz ciało sportowca, ergo ciało adekwatnie ukształtowane, co potocznie jest często ujmowane jako tak zwane wysportowanie" (Czerner 2013: 161).

\section{Podsumowanie}

Na koniec przedstawionych rozważań warto jeszcze poruszyć dwie kwestie. Pierwsza z nich dotyczy uniwersalności kategorii teoretycznych stosowanych przez Ruth Benedict. Należy się zastanowić, na ile pojęcia apollińskości oraz dionizyjskości dotyczą wyłącznie kultury indiańskiej, na ile natomiast są swego rodzaju kulturowymi uniwersaliami. Na pierwszy rzut oka wydawać się może, że badaczka ta opisała dosyć egzotyczne praktyki rdzennych plemion Ameryki. Przeciętnemu przedstawicielowi cywilizacji zachodniej wydawać się może, że tego typu zachowania mogą wynikać z dziwnych wierzeń religijnych bądź też zacofania społecznego, a co za tym idzie również mentalnego badanych grup. Jeżeli jednak rozważy się tę kwestię w kontekście praktyki, jaką jest bieganie ultramaratonów, to sprawa zaczyna wyglądać inaczej. Apollińskość i dionizyjskość stają się bardziej uniwersalnymi kategoriami opisującymi ludzką mentalność i wyjaśniającymi różne, często na pierwszy rzut oka niezrozumiałe, zachowania ludzi. Trzeba jednak pamiętać, o czym wspomina sama R. Benedict, że nie należy szukać prostych analogii między kulturą Greków a kulturą Indian, tak też nie powinno się stawiać znaku równości między zwyczajami Indian a mentalnością uczestników ultramaratonów. Przytoczone pojęcia apollińskości i dionizyjskości posłużyły tu jedynie do ukazania pewnych analogii między różnymi kulturami, a nie jako uniwersalne wzory.

Z kolei druga kwestia podsumowująca tę pracę zawiera sugestie co do dalszych badań. Dotyczy to w znacznej mierze cielesności jako relewantnego aspektu w badaniach społecznych. Na ten metodologiczny wymiar opisywania społeczeństwa zwraca uwagę Loic Wacquant. Według niego socjologia ma badać „smak i ból działania”. Autor ten stwierdza: „Socjologia musi dążyć do uchwycenia i przywrócenia tego cielesnego wymiaru egzystencji, który jest szczególnie dostrzegalny w przypadku boksera, ale jest podzielany w różnym stopniu dostrzegalności przez wszystkie kobiety i mężczyzn, poprzez metodyczną i skrupulatną pracę wykrywania i dokumentowania, odszyfrowywania i pisania podatnego na zdobycie i przeniesienie smaku i bólu działania, dźwięku i furii świata społecznego, które ugruntowane podejścia w naukach społecznych zazwyczaj thumią, 
a nawet likwidują je wszystkie razem" (Wacquant 2004: vii). L. Wacquant sformułował ten postulat odnośnie do swoich badań etnograficznych nad klubem bokserskim. W ramach tego projektu sugerował też, że badacz musi osobiście uczestniczyć w badanym zjawisku, aby naprawdę je poznać: „Aby zrozumieć uniwersum boksu, badacz musi zagłębić się w nim, nauczyć się go i doświadczać od wewnątrz, intus et in cute. Naturalne pojęcie danego obiektu jest tu warunkiem koniecznym dla zdobycia adekwatnej wiedzy o tym obiekcie" (Wacquant 1992: 237). Autor tej pracy przychyla się do zdania L. Wacquanta i stwierdza, że współczesnej socjologii brakuje takiego cielesnego podejścia metodologicznego, które wydaje się szczególnie przydatne w badaniu biegania, w tym także ultramaratonów. Uświadomienie czytelnikowi tych dwóch wymienionych wyżej kwestii - to jest $z$ jednej strony głębszego kulturowego znaczenia biegania w ultramaratonach, z drugiej pewnych braków w badaniach socjologicznych, które warte są wypełnienia - było głównym celem tej pracy.

\section{Bibliografia}

Benedict R. (1922), The Vision in Plains Culture, "American Anthropologist", New Series, vol. 24 (1), s. 1-23.

Benedict R. (2011), Wzory kultury, Wydawnictwo Muza, Warszawa.

Czerner A. (2013), Samotność dlugodystansowca? Społeczny i kulturowy wymiar sportowego stylu życia, Wydawnictwo Uniwersytetu Śląskiego, Katowice.

Jeran A. (2004), Internet jako narzędzie i przedmiot badań, „Kultura i Społeczeństwo”, nr 4, s. $179-186$.

Kłoskowska A. (2011), Różnorodność wzorów kultury i funkcje antropologii kulturalnej, [w:] R. Benedict, Wzory kultury, Wydawnictwo Muza, Warszawa.

Nietzsche F. (2009), Narodziny tragedii z ducha muzyki, Wydawnictwo Aletheia, Warszawa.

Olcoń-Kubicka M. (2006), Blogi jako przejaw wspótczesnego trybalizmu, [w:] D. Batorski, M. Marody, A. Nowak (red.), Spoleczna przestrzeń internetu, Wydawnictwo SWPS „Academica”, Warszawa.

Piszczek Z. (red.) (1983), Mała encyklopedia kultury antycznej, Państwowe Wydawnictwo Naukowe, Warszawa.

Stempień J. R. (2016), Ku źródlom polskiej mody na bieganie - perspektywa nietzscheańska, „Acta Universitatis Lodziensis. Folia Sociologica”, nr 58, s. 47-59.

Sweet D. (1999), The Birth of ,, The Birth of Tragedy", "Journal of the History of Ideas", vol. 60 (2), s. $345-359$.

Szpunar M. (2005), Internet jako pole poszukiwania i konstruowania własnej tożsamości, [w:] E. Hałas, K. Konecki (red.), Konstruowanie jaźni i społeczeństwa. Europejskie warianty interakcjonizmu symbolicznego, Wydawnictwo Scholar, Warszawa.

Tatarkiewicz W. (1988), Historia filozofii. Tom trzeci, Państwowe Wydawnictwo Naukowe, Warszawa.

Wacquant L. (1992), The social logic of boxing in black Chicago - Toward a sociology of pugilism, "Sociology of Sport Journal", no. 9, s. 221-254.

Wacquant L. (2004), Body \& Soul. Notebooks of an Apprentice Boxer, Oxford University Press, New York.

Winniczuk L. (red.) (1986), Stownik kultury antycznej, Wiedza Powszechna, Warszawa. 


\author{
Źródla internetowe \\ bycjakfilipides.pl/najdluzszy-dzien-czyli-xii-bieg-rzeznika-cz-1/ \\ bycjakfilipides.pl/najdluzszy-dzien-czyli-12-bieg-rzeznika-cz-2/ \\ lepiejbiegac.pl/2017/06/bieg-rzeznika-ultra-140/ \\ pl.wikipedia.org/wiki/Apollo_(mitologia) \\ pl.wikipedia.org/wiki/Dionizje \\ pl.wikipedia.org/wiki/Igrzyska_pytyjskie
}

\title{
Adam Kosznicki
}

\section{APOLLONIAN AND DIONYSIAN AS THE CATEGORIES OF SPORT EXPERIENCE. THE INTERPRETATION OF WRITTEN STORIES FROM ULTRAMARATHONS IN THE LIGHT OF THE THEORY OF RUTH BENEDICT}

Summary. This article in its empirical part is devoted to the interpretation of the content of blogs about ultramarathons, i.e. runs at a longer distance than a standard marathon $(42,195 \mathrm{~km})$. This subdiscipline of long-distance running is now rapidly growing and constantly attracting new participants, which is accompanied by fast development of the blogosphere dedicated to this subject. However, online diaries of runners have not yet been analysed too comprehensively by social researchers. Therefore, this work will be an attempt to fill in this empirical gap, and the content of the examined blogs will be used to understand the practice of participation in ultramarathons. The theoretical basis of this work is Ruth Benedict's considerations and her concepts of apollonian and dionysian as aspects of culture. These notions were borrowed from F. Nietzsche and used in the description of North American Indian culture. The main research goal set by the author is an attempt to analyse the forms of manifestations of the apollonian and dionysian elements in written stories from ultramarathons. For analysing the textual content of blogs the author will use the personal documents method. The summary contains the conclusions from the whole inquiry and the suggestions for further sociological research.

Key words: apollonian, dionysian, Friedrich Nietzsche, Ruth Benedict, ultramarathons, blogs, personal documents method. 